\title{
Examination of Educational Support for Students' Stress in Nursing Practicums
}

\author{
Emi Yoshioka1, Sayuri Kaneko² \\ ${ }^{1}$ Nagano College of Nursing, Komagane, Japan \\ ${ }^{2}$ Miyagi University, Sendai, Japan \\ Email: eyoshioka@nagano-nurs.ac.jp,Kanekos@myu.ac.jp
}

How to cite this paper: Yoshioka, E., \& Kaneko, S. (2021). Examination of Educational Support for Students' Stress in Nursing Practicums. Open Journal of Social Sciences, 9, 496-515.

https://doi.org/10.4236/jss.2021.97036

Received: June 2, 2021

Accepted: July 26, 2021

Published: July 29, 2021

Copyright (c) 2021 by author(s) and Scientific Research Publishing Inc. This work is licensed under the Creative Commons Attribution International License (CC BY 4.0).

http://creativecommons.org/licenses/by/4.0/

(c) (i) Open Access

\begin{abstract}
Aim: To clarify students' stress factors, sense of coherence, stress-coping behavior, and stress reactions during nursing practice, and develop recommendations for educational support. Method: We conducted a search of literature published in the period 2009-2020, using the Igaku Chuo Zasshi, MEDLINE, and CINAHL, and the keywords "nursing student," "stress," and "nursing practice." Results: Twenty articles were included in the review. As a result, the stress factors were a nursing process and record common to all grades. Sense of coherence tended to be higher among nursing students than for students in other faculties. As for stress-coping behavior, students selected "Avoidance and suppression" in specialty I. In nursing integration, students chose "Active solution.” Regarding stress reaction, students' mental health was low during nursing practice, and their thinking and concentration abilities continued to decline even after practice. Conclusion: As teachers develop a better understanding of stress factors and their contexts, students will assess trends in stress-coping behavior to guide lessons and reflect on coping with stress.
\end{abstract}

\section{Keywords}

Nursing Practice, Stress Factors, Sense of Coherence, Stress-Coping Behavior, Stress Reaction

\section{Introduction}

With the advancement of medicine and changes in the structure of diseases, there is an increase in demand for improved health and medical services. Therefore, nurses are expected to improve their practical nursing skills and the quality of care. Nursing practicums provide nursing students with valuable learning opportunities and help them acquire practical nursing skills. Meanwhile, during 
a practicum, students experience an environment that is different from what they are familiar with. Nowadays, students interact with fewer people during their childhood. Therefore, a nursing practicum can be a source of significant stress for them (Nakajima, 1990). Students can experience reduced motivation and self-efficacy if they chronically face difficulties in alleviating stress. In such a situation, they are unable to effectively address it (Munakata, 2000). Especially in Japan, the problem of turnover due to burnout of new nurses has become apparent, and it is required to improve the stress coping ability of nursing students.

Individuals, including nurses, can experience stress in life. It is important for them to accurately understand and manage it (Kageyama \& Kobayashi, 2017). Stress-coping skills include a sense of coherence (SOC). Antonovsky (1987, 2008) defined the SOC as a stress-coping skill to effectively address stressful events and situations, and maintain health. He stated that the SOC can be enhanced by coping with stress. In other words, nursing students are enhancing their SOC while experiencing various types of stress during a nursing practicum which is a preparation period for them to acquire a new role as a professional. Whether a student has successfully addressed stress or not during a nursing practicum affects their subsequent attitude toward studying nursing (Hasegawa et al., 2010). It is a pressing issue to provide students with educational support to enhance their SOC and stress-coping behaviors.

Hence, in this study we reviewed papers that are focused on stress caused by a practicum in nursing students. From the study, we obtained suggestions for educational support for enhancing the SOC and stress-coping behaviors of students by elucidating their stress factors, the SOC, stress-coping behaviors, and stress reaction.

\section{Aim}

In this study, we aimed to shed light on stress factors, the SOC, stress-coping behaviors, and stress reaction in students participating in a nursing practicum. We conducted a literature search and obtained suggestions for educational support to enhance the SOC and stress-coping behaviors of students.

\section{Study Methods}

\subsection{Literature Search}

A literature search was conducted using Ichushi-Web version 5 (Igaku Chuo Zasshi), and EBSCO (MEDLINE, CINAHL). The search period was from 2009 to April 2020. During this period, the Japanese government issued "A Report on the Discussion Meeting on the Improvement of Basic Nursing Education" (Ministry of Health, Labour and Welfare, 2007), and the current curriculum was implemented.

Ichushi-Web version 5 was used to search for papers published in Japan. The following keywords were used during the search: "nursing students," "stress," and "nursing practicum." The search was limited to original papers. 
The researchers reviewed the abstracts of 56 extracted papers, and selected 16 which were aligned with the aim of this study. To search for papers published outside Japan, EBSCO (MEDLINE, CINAHL) was used with the following keywords: "nursing students," "stress," and "nursing practice." The search was limited to research articles. The researchers reviewed the abstracts of 51 extracted papers and selected four that aligned with the aim of this study. Through the above-mentioned process, a total of 20 papers from Japan and overseas were identified for examination.

\subsection{Analysis Methods}

For the analysis of the papers, the researchers focused on descriptions that mention the trend in studies on stress in nursing practicums, stress factors, the SOC, stress-coping behaviors, and stress reaction. Then, the relevant parts were extracted. This analysis is performed among researchers throughout the analysis process.

The validity of the discussion analysis has been improved.

\subsection{Ethical Considerations}

The researchers respected the copyrights of the papers examined, and ensured that citations were accurate.

\section{Results}

The 20 papers extracted are listed in Table 1 . It is followed by a discussion on the trend in studies on stress, stress factors, the SOC, stress-coping behaviors, and stress reaction.

\subsection{The Trend in Studies on Stress in Nursing Practicums}

A review of papers on stress in nursing practicums by area found that two papers were categorized as "Basic Nursing Practicum I," and three as "Basic Nursing Practicum II." These two types of practicums were considered as Specialty I. For Specialty II, two papers were categorized as adult nursing practicum, one as a geriatric nursing practicum, two as maternal health nursing practicum, and two as psychiatric nursing practicum. No papers were categorized as pediatric nursing practicum. For integrated areas, two papers were categorized as home nursing practicum, and one as nursing integration and practical practicum. Five papers did not belong to any area or discipline.

\subsection{Stress Factors in Nursing Practicums}

A review of stress factors in nursing practicums found that they were related to Basic Nursing Practicum I including "relationship with teachers and instructors" and "relationship with patients, families, and healthcare staff" (Kaneko \& Momino, 2015a). Stress factors specific to Basic Nursing Practicum II were "progress in the course of nursing" and "regular practicum plans" (Kaneko \& Momino, 2015b). 
Table 1. Stress factors, the sense of coherence, stress-coping behaviors, and stress reactions in examined papers.

\begin{tabular}{|c|c|c|c|c|c|}
\hline \multirow{2}{*}{$\begin{array}{l}\text { Discipline } \\
\text { Paper No. }\end{array}$} & \multicolumn{5}{|c|}{ Basic nursing } \\
\hline & 1 & 2 & 3 & 4 & 5 \\
\hline Title & $\begin{array}{l}\text { Changes in Sense of } \\
\text { Coherence (SOC) } \\
\text { among Nursing } \\
\text { Students Undergoing } \\
\text { Fundamental Nursing } \\
\text { Clinical Practice, and } \\
\text { Related Stress Factors }\end{array}$ & $\begin{array}{l}\text { Stress Factors and } \\
\text { Coping Behaviors of } \\
\text { Nursing Students } \\
\text { during Fundamental } \\
\text { Clinical Practice }\end{array}$ & $\begin{array}{l}\text { Stress Factors and } \\
\text { Coping Behaviors in } \\
\text { Nursing Students } \\
\text { During Fundamental } \\
\text { Clinical Training in } \\
\text { Japan }\end{array}$ & $\begin{array}{l}\text { Relationship between } \\
\text { Stress Coping Skills and } \\
\text { Stress Factors during } \\
\text { Clinical Practice of } \\
\text { Nursing Students }\end{array}$ & $\begin{array}{l}\text { The Relationships } \\
\text { among } \\
\text { Self-Consciousness, } \\
\text { Other-Consciousness } \\
\text { and Sense of Coherence }\end{array}$ \\
\hline $\begin{array}{l}\text { Primary author } \\
\text { (publication year) }\end{array}$ & $\begin{array}{l}\text { Momino \& Kaneko } \\
\text { (2016) }\end{array}$ & $\begin{array}{l}\text { Kaneko \& Momino, } \\
\text { (2015a) }\end{array}$ & $\begin{array}{l}\text { Kaneko, S \& Momino } \\
(2015 b)\end{array}$ & Usui et al. (2014) & Hongo et al. (2011) \\
\hline Aim & $\begin{array}{l}\text { To shed light on how } \\
\text { the sense of coherence } \\
\text { of students changed } \\
\text { after a practicum in } \\
\text { basic nursing and which } \\
\text { stress factors of the } \\
\text { practicum are } \\
\text { associated with such } \\
\text { changes. }\end{array}$ & $\begin{array}{l}\text { To shed light on the } \\
\text { structure of stress } \\
\text { factors in nursing } \\
\text { students during a } \\
\text { practicum in basic } \\
\text { nursing; elucidate the } \\
\text { relationship between } \\
\text { stress factors and } \\
\text { stress-coping behaviors } \\
\text { during a clinical } \\
\text { practicum by taking } \\
\text { into account the SOC of } \\
\text { students; and examine } \\
\text { how practicums in } \\
\text { basic nursing can be } \\
\text { improved. }\end{array}$ & $\begin{array}{l}\text { To elucidate the } \\
\text { structure of stress } \\
\text { factors during a } \\
\text { practicum in basic } \\
\text { nursing, and validate } \\
\text { the relationship } \\
\text { between stress factors } \\
\text { and stress-coping } \\
\text { behaviors in nursing } \\
\text { students. }\end{array}$ & $\begin{array}{l}\text { To shed light on the } \\
\text { impact of the SOC prior } \\
\text { to a practicum in basic } \\
\text { nursing on the stress } \\
\text { and stress-coping } \\
\text { behaviors of year-two } \\
\text { students at University } \\
\text { A; and examine the } \\
\text { system of instructions } \\
\text { for the basic nursing } \\
\text { practicum. }\end{array}$ & $\begin{array}{l}\text { To shed light on the } \\
\text { relationship between } \\
\text { the SOC of nursing } \\
\text { students and their } \\
\text { awareness of self and } \\
\text { others. }\end{array}$ \\
\hline $\begin{array}{l}\text { Participant, } \\
\text { study period }\end{array}$ & $\begin{array}{l}\text { A total of } 158 \\
\text { students from the } \\
\text { Department of } \\
\text { Nursing of University } \\
\text { A, comprising } 82 \\
\text { students enrolled in } \\
2011 \text { and } 76 \text { in } 2012 \text {. }\end{array}$ & $\begin{array}{l}\text { A total of } 158 \\
\text { students from the } \\
\text { Department of } \\
\text { Nursing of } \\
\text { University A, } \\
\text { comprising } 82 \\
\text { students enrolled } \\
\text { in u2011 and } \\
76 \text { in } 2012 \text {. }\end{array}$ & $\begin{array}{l}\text { A total of } 158 \\
\text { first-year students } \\
\text { from a nursing } \\
\text { department, } \\
\text { comprising of } 79 \\
\text { students enrolled in } \\
\text { the course in } 2012 \\
\text { and } 79 \text { in } 2013 .\end{array}$ & $\begin{array}{l}\text { A total of } 158 \\
\text { students from the } \\
\text { Department of } \\
\text { Nursing of University } \\
\text { A, comprising } 82 \\
\text { students enrolled in } \\
2011 \text { and } 76 \text { in } 2012 \text {. }\end{array}$ & $\begin{array}{l}\text { A total of } 73 \text { first-year } \\
\text { students at Nursing } \\
\text { University A (those } \\
\text { who were about to } \\
\text { start Basic Nursing } \\
\text { Practicum I). } \\
\text { - The study was } \\
\text { conducted in } \\
\text { February } 2010 \text {. }\end{array}$ \\
\hline Stress factor & & $\begin{array}{l}\text { The structure of stress } \\
\text { factors was extracted for } \\
\text { the following: } \\
\text { - Progress in the } \\
\text { nursing course } \\
\text { - Relationship with } \\
\text { teachers and } \\
\text { instructors } \\
\text { - Relationship with } \\
\text { patients, families, and } \\
\text { health professionals } \\
\text { - Lack of knowledge } \\
\text { and skills } \\
\text { - Regular practicum } \\
\text { plans } \\
\text { - Briefings } \\
\text { - Relationship } \\
\text { between students }\end{array}$ & $\begin{array}{l}\text { The structure of stress } \\
\text { factors was extracted for } \\
\text { the following: } \\
\text { - Relationship with } \\
\text { teachers and } \\
\text { instructors } \\
\text { - Lack of knowledge } \\
\text { and skills } \\
\text { - Reflection on care } \\
\text { for patients } \\
\text { - Relationship with } \\
\text { patients, families, } \\
\text { and health care staff } \\
\text { - Briefings } \\
\text { - Relationship } \\
\text { between students } \\
\text { - Regular practicum } \\
\text { plans }\end{array}$ & $\begin{array}{l}\text { Through a review of } \\
\text { previous studies, } 29 \\
\text { items were extracted. }\end{array}$ & \\
\hline
\end{tabular}




\section{Continued}

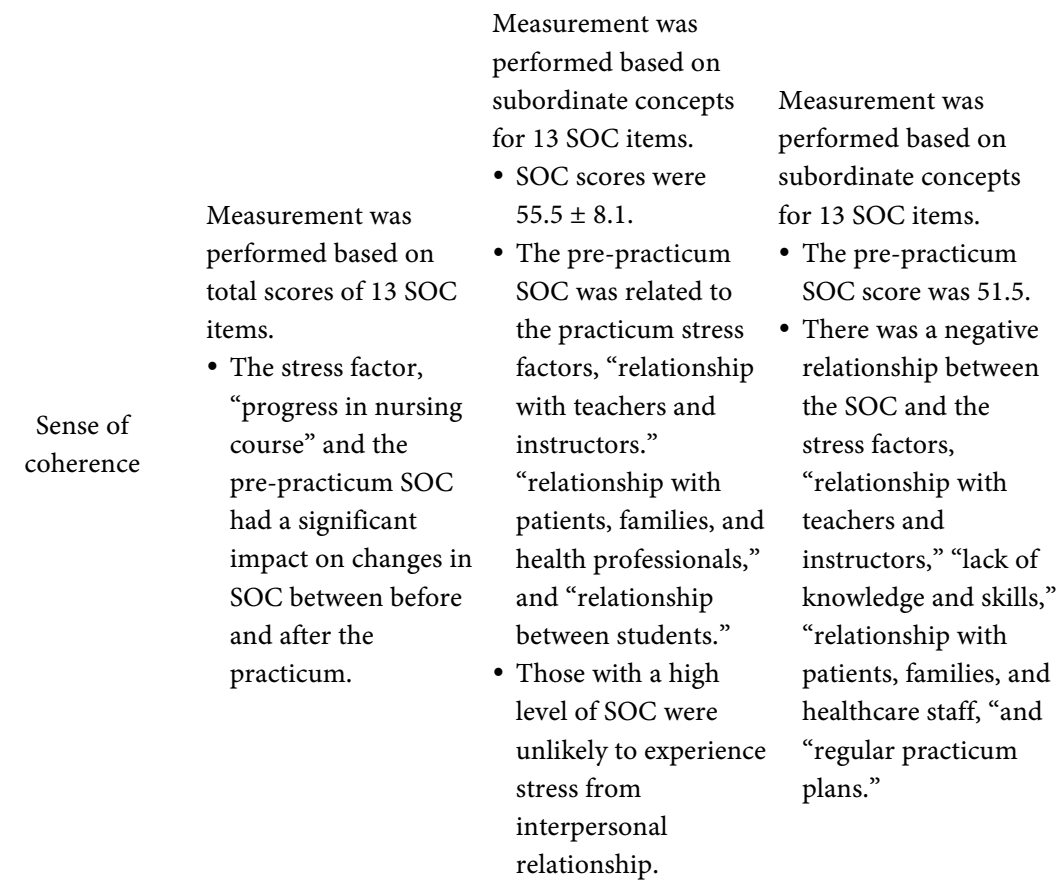

\section{inued}

Stress-coping behavior

$\begin{array}{lll}\begin{array}{l}\text { Measurement was } \\ \text { performed based on }\end{array} & \begin{array}{l}\text { Measurement was } \\ \text { performed based on }\end{array} \\ 18 \text { BSCP items. } & \text { 18 BSCP items. } \\ \text { - The stress factor, } & \text { - The stress factor, } \\ \text { "relationship with } & \text { "relationship with } \\ \text { teachers and } & \text { teachers and } \\ \text { instructors," was } & \text { instructors," was } \\ \text { related to the BSCP } & \text { related to the BSCP } \\ \text { item, "avoidance and } & \text { item, "distraction } \\ \text { suppression." } & \text { from the situation." } \\ \text { - The stress factor, } & \text { - The stress factors, } \\ \text { "relationship with } & \text { "lack of knowledge } \\ \text { patients, families, } & \text { and skills," } \\ \text { and health } & \text { "reflection on care } \\ \text { professionals," } & \text { for patients," } \\ \text { was related to the } & \text { and "briefings" } \\ \text { BSCP item, } & \text { were related to the } \\ \text { "emotional } & \text { BSCP item, } \\ \text { expression } & \text { "active solution." } \\ \text { involving others." } & \end{array}$

Measurement was performed based on subordinate concepts for 13 SOC items.

- Scores for the following SOC items were higher in participants with a high SOC score than in those with a low SOC score: "sense of comprehensibility," "sense of manageability," and "sense of meaningfulness."
Measurement was performed based on total scores for

13 SOC items.

- SOC scores were $49.6 \pm 9.3$.

- A negative correlation was observed between the SOC and stress from the practicum.

- Compared to participants with high a SOC, those with a low SOC tend to be introverted and feel that they are being assessed by others.

- Compared to participants with a low SOC, those with a high SOC strongly tend to have high self-esteem. They have a sense of satisfaction, feel self-actualization, and are able to express themselves.
Measurement was performed based on 12 items that were extracted through a review of previous studies.

- Compared to participants with a high SOC score, a significantly higher proportion of participants with a low SOC score engaged in two types of stress-coping behaviors: "giving up on resolving issues, and leaving them unaddressed or putting them off," and "putting up with the stress, not knowing how to address it." 


\begin{tabular}{|c|c|c|c|c|c|}
\hline \multirow{2}{*}{$\begin{array}{l}\text { Discipline } \\
\text { Paper No. }\end{array}$} & \multicolumn{2}{|c|}{ Adult nursing } & \multirow{2}{*}{$\begin{array}{c}\text { Geriatric nursing } \\
8\end{array}$} & \multicolumn{2}{|c|}{ Maternal health nursing } \\
\hline & 6 & 7 & & 9 & 10 \\
\hline Title & $\begin{array}{l}\text { Changes in Mental } \\
\text { Health Status and } \\
\text { Stress/Coping of } \\
\text { Students in Nursing } \\
\text { Practice for the } \\
\text { Perioperative/Acute } \\
\text { Periods }\end{array}$ & $\begin{array}{l}\text { The Survey on } \\
\text { Relationship and } \\
\text { Change of the Sense } \\
\text { of Coherence and } \\
\text { Mental Health Status, } \\
\text { Physical Symptoms, } \\
\text { Life Situations and } \\
\text { Social Situations in } \\
\text { Nursing Students } \\
\text { before and during } \\
\text { Clinical Practice of } \\
\text { Adult Nursing }\end{array}$ & $\begin{array}{l}\text { Relationship between } \\
\text { Stress Responses of } \\
\text { Nursing Students and } \\
\text { Their Active/Rest } \\
\text { Patterns and } \\
\text { Attainment Level in } \\
\text { Geriatric Nursing } \\
\text { Practice }\end{array}$ & $\begin{array}{l}\text { Assignment of } \\
\text { Maternal Nursing } \\
\text { Practicum against } \\
\text { Student's Stress } \\
\text { and Coping }\end{array}$ & $\begin{array}{l}\text { Stress of the Student in } \\
\text { Maternity Science } \\
\text { of-Nursing Training } \\
\text { Male and Female } \\
\text { Comparison }\end{array}$ \\
\hline $\begin{array}{l}\text { Primary } \\
\text { author }\end{array}$ & Kikuchi et al. (2018) & Yamanaka et al. (2018) & Tsutsumi et al. (2019) & $\begin{array}{l}\text { Nakajima \& Hyakawa } \\
(2014)\end{array}$ & Ogura et al. (2013) \\
\hline Aim & $\begin{array}{l}\text { To maintain the } \\
\text { mental health of } \\
\text { nursing students, } \\
\text { the study compared } \\
\text { changes in their } \\
\text { scores of General } \\
\text { Health Questionnaire } \\
\text { (GHQ-12) before the } \\
\text { practicum and on the } \\
\text { final day of the } \\
\text { practicum. The study } \\
\text { also explored ways to } \\
\text { improve the } \\
\text { practicum } \\
\text { environment and } \\
\text { support by examining } \\
\text { how students cope } \\
\text { with their stress } \\
\text { during the clinical } \\
\text { practicum. }\end{array}$ & $\begin{array}{l}\text { To shed light on the } \\
\text { following: the sense of } \\
\text { coherence (SOC) in } \\
\text { nursing students before } \\
\text { an adult nursing } \\
\text { practicum and in week } \\
3 \text { of the practicum; } \\
\text { changes in their mental } \\
\text { health, physical } \\
\text { symptoms, and social } \\
\text { situations; and the } \\
\text { relationships between } \\
\text { the SOC and the } \\
\text { aforementioned aspects. }\end{array}$ & $\begin{array}{l}\text { To elucidate tactivities } \\
\text { and rest of students } \\
\text { during a practicum in } \\
\text { geriatric nursing as well } \\
\text { as the relationship } \\
\text { between stress and the } \\
\text { degree of goal } \\
\text { achievement in the } \\
\text { practicum. }\end{array}$ & $\begin{array}{l}\text { To examine issues with } \\
\text { instructions for } \\
\text { practicums in maternal } \\
\text { health nursing by } \\
\text { shedding light on the } \\
\text { stress and stress-coping } \\
\text { behaviors of students } \\
\text { during a practicum in } \\
\text { the area. }\end{array}$ & $\begin{array}{l}\text { To elucidate the } \\
\text { physical and mental } \\
\text { stress of nursing } \\
\text { students before and } \\
\text { after a practicum in } \\
\text { maternal health } \\
\text { nursing. }\end{array}$ \\
\hline $\begin{array}{l}\text { Participant, } \\
\text { study period }\end{array}$ & $\begin{array}{l}\text { - A total of } 54 \\
\text { third-year students at } \\
\text { Nursing University A, } \\
\text { enrolled in a } \\
\text { practicum on } \\
\text { acute-stage care in } \\
2012 . \\
\text { - The study was } \\
\text { conducted from } \\
\text { September } 2012 \text { to } \\
\text { January } 2013 \text {. }\end{array}$ & $\begin{array}{l}\text { A total of } 153 \\
\text { nursing students, } \\
\text { comprising } 86 \\
\text { third-year students } \\
\text { and } 67 \text { fourth-year } \\
\text { students from the } \\
\text { Department of } \\
\text { Nursing of } \\
\text { University A, } \\
\text { enrolled in Adult } \\
\text { Nursing Practicum } \\
\text { I (acute care) and } \\
\text { Adult Nursing } \\
\text { Practicum II } \\
\text { (chronic care). } \\
\text { The study was } \\
\text { conducted from } \\
\text { May to December } \\
\text { 2015. }\end{array}$ & $\begin{array}{l}\text { A total of } 77 \\
\text { fourth-year students } \\
\text { enrolled in a nursing } \\
\text { course of the } \\
\text { department of } \\
\text { health sciences of } \\
\text { University A School } \\
\text { of Medicine as in } \\
2018 . \\
\text { The study was } \\
\text { conducted from } \\
\text { April to June } 2018 \text {. }\end{array}$ & $\begin{array}{l}\text { - A total } 75 \text { of nursing } \\
\text { students in } \\
\text { University A, } \\
\text { who completed a } \\
\text { practicum in } \\
\text { maternal health } \\
\text { nursing in } 2012 \text {. } \\
\text { - The study was } \\
\text { conducted from } \\
\text { September } 2012 \text { to } \\
\text { January } 2013\end{array}$ & $\begin{array}{l}\text { - A total of } 65 \\
\text { third-year students } \\
\text { enrolled in a } \\
\text { practicum in } \\
\text { maternal health } \\
\text { nursing at the } \\
\text { Department of } \\
\text { Nursing of } \\
\text { University A in } 2012 . \\
\text { - The study was } \\
\text { conducted from } \\
\text { November to } \\
\text { December } 2012\end{array}$ \\
\hline
\end{tabular}




\section{Continued}

Stress factor

Sense of

coherence

$\begin{array}{cl} & \text { Twelve items adapted } \\ & \text { from a stress and } \\ & \text { coping scale as well as } \\ & \text { free descriptions. } \\ & \text { - } \\ & \text { There was a moderate } \\ \text { negative correlation } \\ \text { Stress-coping } & \text { for the } \\ \text { behavior } & \text { "problem-focused" } \\ & \text { type. Participants } \\ & \text { with a higher level of } \\ & \text { stress could not } \\ & \text { practice } \\ & \text { problem-focused-type } \\ & \text { coping. }\end{array}$

Developed by 13 items

for stress from

practicuums were

adapted and used.

- Issues related to the

practicum facility

- Issues related to the nursing course

- Issues related to the practicum record and self-learning

- Issues related to practicum times

- Issues related to the duration of the practicum, expenses for travel and accommodation
Measurement was performed based on total scores for $13 \mathrm{SOC}$

items.

- Total SOC scores were $54.6 \pm 9.5$.

- No changes in SOC were observed between before the practicum and weeks 1,2 , or 3 of the practicum.
Free descriptions in a self-administered questionnaire on stress were categorized into the following:

- "Inexperience, anxiety, and nervousness associated with reporting"; "frustration, anxiety, and nervousness accompanying a lack of practical nursing skills"; "difficulties in adjusting time for nursing support and observation";

"hesitation and a sense of isolation in male students when providing nursing support"; "a sense of bewilderment due to the gap in approaches to instructions between teachers and clinical instructors."
Measurement was performed using the Coping Strategy Scale

- For a practicum in ward settings, the number of "problem-focused" participants was higher than that of "emotion-centered" ones.

- "Problem-focused" participants engaged in stress-coping behaviors such as "preparing for the practicum by learning necessary knowledge beforehand." 


\begin{tabular}{|c|c|c|c|c|c|}
\hline Stress reaction & $\begin{array}{l}\text { Measurement was } \\
\text { performed based on } \\
\text { the } 12 \text { items of the } \\
\text { GHQ-12. } \\
\text { - Scores of the } \\
\text { GHQ-12 were as } \\
\text { follows: } \\
4.4 \pm 3.3 \text { before the } \\
\text { practicum and } \\
7.1 \pm 3.1 \text { on the } \\
\text { final day of the } \\
\text { practicum. }\end{array}$ & $\begin{array}{l}\text { Measurement was } \\
\text { performed based on the } \\
12 \text { items of the General } \\
\text { Health Questionnaire } \\
\text { (GHQ)-12 } \\
\text { - Scores of the } \\
\text { GHQ-12 were as } \\
\text { follows: } 15.2 \pm 4.9 \\
\text { before the practicum, } \\
8.2 \pm 4.7 \text { at week } 1 \text { of } \\
\text { the practicum; } \\
18.0 \pm 4.9 \text { at week } 2 \text {; } \\
\text { and } 17.5 \pm 5.4 \text { at } \\
\text { week } 3 \\
\text { - There were significant } \\
\text { differences in } \\
\text { GHQ-12 scores, } \\
\text { physical symptoms, } \\
\text { living circumstances, } \\
\text { and social situations } \\
\text { between the following } \\
\text { time points: before } \\
\text { the practicum and } \\
\text { week } 1 \text { of the } \\
\text { practicum; before } \\
\text { the practicum and } \\
\text { week } 2 \text {; and before } \\
\text { the practicum and } \\
\text { week } 3 \text {. }\end{array}$ & $\begin{array}{l}\text { Developed by reference } \\
\text { to the Cumulative } \\
\text { Fatigue Symptoms } \\
\text { Index (CFSI), } 29 \text { items } \\
\text { of a stress reaction } \\
\text { questionnaire were } \\
\text { created. } \\
\text { - Mean scores for the } \\
\text { following stress } \\
\text { reaction items were } \\
\text { high after the } \\
\text { completion of the } \\
\text { practicum: "anxiety } \\
\text { and depression," } \\
\text { "reduced motivation," } \\
\text { and "chronic fatigue." }\end{array}$ & & $\begin{array}{l}\text { Physical stress was } \\
\text { measured by the } \\
\text { salivary amylase } \\
\text { monitor, Kokoro Meter, } \\
\text { moods were measured } \\
\text { by } 30 \text { items of the } \\
\text { simple version of the } \\
\text { POMS. } \\
\text { - Male students showed } \\
\text { competition/aversion } \\
\text { reaction to } \\
\text { practicums; however, } \\
\text { their stress reaction } \\
\text { was reduced as they } \\
\text { progressed in the } \\
\text { practicum. } \\
\text { - Scores for the POMS } \\
\text { items, "fatigue" and } \\
\text { "bewilderment" were } \\
\text { higher after the } \\
\text { practicum. } \\
\text { Participants did not } \\
\text { recover quickly from } \\
\text { fatigue after the } \\
\text { practicum, and } \\
\text { exhibited persistent } \\
\text { low thinking ability } \\
\text { and concentration. }\end{array}$ \\
\hline Discipline & \multicolumn{2}{|c|}{ Psychiatric nursing } & \multicolumn{2}{|c|}{ Community/Home nursing } & Nursing integration \\
\hline Paper No. & 11 & 12 & 13 & 14 & 15 \\
\hline Title & $\begin{array}{l}\text { Coping with } \\
\text { Interpersonal Stress } \\
\text { by Nursing Students } \\
\text { in Psychiatric } \\
\text { Mental Health } \\
\text { Nursing Practice }\end{array}$ & $\begin{array}{l}\text { Psychological Stress } \\
\text { of Nursing Students } \\
\text { in Psychiatric } \\
\text { Mental Health } \\
\text { Nursing Practice }\end{array}$ & $\begin{array}{l}\text { Stressors for Students } \\
\text { before a Community } \\
\text { Nursing Practicum, } \\
\text { and Their Coping } \\
\text { Behaviors }\end{array}$ & $\begin{array}{l}\text { The Relationship } \\
\text { between the Level of } \\
\text { Mental Health and } \\
\text { Coping in Community } \\
\text { Nursing Practicums: } \\
\text { A Comparative } \\
\text { Examination before } \\
\text { and after the Practicum }\end{array}$ & $\begin{array}{l}\text { Stress Factors and } \\
\text { Stress Coping } \\
\text { Competence and } \\
\text { Behavior among } \\
\text { Nursing Students } \\
\text { Providing Nursing } \\
\text { Comprehensive } \\
\text { Practice }\end{array}$ \\
\hline $\begin{array}{c}\text { Primary } \\
\text { author }\end{array}$ & Takahashi et al. (2011) & Kosaka (2010) & Inoue \& Totsuka (2010) & Inoue \& Totsuka (2011) & Yoshioka et al. (2019) \\
\hline Aim & $\begin{array}{l}\text { To shed light on the } \\
\text { characteristics of } \\
\text { coping with } \\
\text { interpersonal stress by } \\
\text { nursing students } \\
\text { during a practicum in } \\
\text { psychiatric nursing } \\
\text { from perspectives of } \\
\text { personality disposition } \\
\text { and stress reaction. }\end{array}$ & $\begin{array}{l}\text { Physical and } \\
\text { psychological stress } \\
\text { factor items developed } \\
\text { by the authors were } \\
\text { used to examine the } \\
\text { psychological stress of } \\
\text { nursing students in } \\
\text { clinical practicums. } \\
\text { The study compared } \\
\text { the items between } \\
\text { psychiatric nursing } \\
\text { practicums and adult } \\
\text { nursing ones, and } \\
\text { identified the } \\
\text { differences. }\end{array}$ & $\begin{array}{l}\text { 1) To clarify stressors } \\
\text { for students before a } \\
\text { community nursing } \\
\text { practicum. } \\
\text { 2) To shed light on } \\
\text { behaviors of coping } \\
\text { with stressors. } \\
\text { 3) To clarify the state of } \\
\text { mental health of } \\
\text { students before a } \\
\text { community nursing } \\
\text { practicum. } \\
\text { 4) To clarify the } \\
\text { relationship between } \\
\text { coping behaviors and } \\
\text { the state of mental } \\
\text { health. }\end{array}$ & $\begin{array}{l}\text { To elucidate the } \\
\text { relationship between } \\
\text { the level of mental } \\
\text { health (GHQ-12) and } \\
\text { coping in nursing } \\
\text { students before and } \\
\text { after a community } \\
\text { nursing practicum, } \\
\text { and examine methods } \\
\text { that can facilitate the } \\
\text { effective } \\
\text { implementation of } \\
\text { practicums without } \\
\text { issues. }\end{array}$ & $\begin{array}{l}\text { The study examined } \\
\text { stress factors in } \\
\text { students during an } \\
\text { nursing integration } \\
\text { practicum. Then, it } \\
\text { elucidated the } \\
\text { relationship between } \\
\text { stress factors, the SOC, } \\
\text { and stress-coping } \\
\text { behaviors. It also } \\
\text { examined methods of } \\
\text { improving nursing } \\
\text { integration practicums } \\
\text { in a scientific and } \\
\text { rational manner based } \\
\text { on validation data. }\end{array}$ \\
\hline
\end{tabular}




\section{Continued}

\begin{tabular}{|c|c|c|c|c|c|}
\hline $\begin{array}{l}\text { Participant, } \\
\text { study period }\end{array}$ & $\begin{array}{l}\text { - A total of third-year } \\
\text { students in Nursing } \\
\text { University A, who } \\
\text { gave consent to } \\
\text { participate in the } \\
\text { study. } \\
\text { - The study was } \\
\text { conducted from } \\
\text { February to March } \\
\text { 2010. }\end{array}$ & $\begin{array}{l}\text { - A total of } 74 \\
\text { third-year students in } \\
\text { four nursing colleges } \\
\text { in the Kinki region, } \\
\text { Japan. } \\
\text { - The study was } \\
\text { conducted from April } \\
\text { to December } 2008 \text {. }\end{array}$ & $\begin{array}{l}\text { - A total of } 77 \\
\text { second-year and } \\
\text { third-year students } \\
\text { who were } \\
\text { participating in a } \\
\text { community nursing } \\
\text { practicum in a } \\
\text { three-year course of } \\
\text { a nursing college. } \\
\text { - The study was } \\
\text { conducted from } \\
\text { January to November } \\
2009 \text {. }\end{array}$ & $\begin{array}{l}\text { - A total of } 150 \\
\text { second-year and } \\
\text { third-year students } \\
\text { who were } \\
\text { participating in a } \\
\text { community-based } \\
\text { practicum from } 2009 \\
\text { to } 2010 \text { in a } \\
\text { three-year course } \\
\text { of a nursing college. } \\
\text { The study was } \\
\text { conducted from } \\
\text { January } 2009 \text { to } \\
\text { November } 2010\end{array}$ & $\begin{array}{l}\text { - A total of } 86 \text { students } \\
\text { who were enrolled in } \\
\text { Nursing University A } \\
\text { as of } 2019 \text {, and who } \\
\text { were scheduled to } \\
\text { participate in a } \\
\text { nursing integration } \\
\text { practicum } \\
\text { - The study was } \\
\text { conducted from } \\
\text { July to August } 2019\end{array}$ \\
\hline Stress factor & & & $\begin{array}{l}\text { Stress factors were } \\
\text { extracted from free } \\
\text { descriptions. } \\
\text { - Stress factors before } \\
\text { the practicum } \\
\text { included: anxiety for } \\
\text { the practicum, } \\
\text { interpersonal } \\
\text { relationship during } \\
\text { the practicum, } \\
\text { practicing healthy } \\
\text { habits, concerns } \\
\text { about practicum } \\
\text { records, and anxiety } \\
\text { for not having } \\
\text { sufficient time to } \\
\text { study. }\end{array}$ & & $\begin{array}{l}\text { Five factors were } \\
\text { extracted, for which } \\
\text { the structure of } \\
\text { stress factors was } \\
\text { confirmed. } \\
\text { - Understanding roles } \\
\text { within the hospital } \\
\text { organization } \\
\text { - Practicing nursing as } \\
\text { a member of a } \\
\text { nursing team } \\
\text { - Adjusting } \\
\text { autonomous nursing } \\
\text { practice with teachers } \\
\text { and instructors } \\
\text { - A nursing course in } \\
\text { which students are } \\
\text { assigned to multiple } \\
\text { patients } \\
\text { - Building a supportive } \\
\text { relationship with } \\
\text { patients and their } \\
\text { family }\end{array}$ \\
\hline $\begin{array}{l}\text { Sense of } \\
\text { coherence }\end{array}$ & & & & & $\begin{array}{l}\text { Measurement was } \\
\text { performed based on } \\
\text { subordinate concepts } \\
\text { for } 13 \text { SOC items. } \\
\text { - Total SOC scores } \\
\text { were } 51.3 \pm 4.6 \text {. } \\
\text { - There were negative } \\
\text { relationships } \\
\text { between the SOC } \\
\text { item, "sense of } \\
\text { meaningfulness" } \\
\text { and the stressors, } \\
\text { "practicing nursing as } \\
\text { a member of a } \\
\text { nursing team" and } \\
\text { "adjusting } \\
\text { autonomous nursing } \\
\text { practice with teachers } \\
\text { and instructors." }\end{array}$ \\
\hline
\end{tabular}




\begin{tabular}{|c|c|c|c|c|c|}
\hline $\begin{array}{l}\text { Stress-coping } \\
\text { behavior }\end{array}$ & $\begin{array}{l}\text { Measurement was } \\
\text { performed based on } \\
34 \text { items of the } \\
\text { Interpersonal Stress } \\
\text { Coping Scale } \\
\text { - Scores for coping } \\
\text { with positive } \\
\text { relationships were } \\
\text { the lowest (1.39). } \\
\text { They increased as } \\
\text { participants } \\
\text { progressed in the } \\
\text { practicum, and } \\
\text { reached the highest } \\
\text { level (1.74) after the } \\
\text { practicum. } \\
\text { - Scores for coping } \\
\text { with negative } \\
\text { relationships } \\
\text { remained unchanged } \\
\text { throughout the entire } \\
\text { practicum period. } \\
\text { They were the highest } \\
\text { (0.83) before the } \\
\text { practicum and the } \\
\text { lowest (0.75) after the } \\
\text { practicum. They } \\
\text { decreased as } \\
\text { participants } \\
\text { progressed in the } \\
\text { practicum. } \\
\text { - Scores for coping } \\
\text { with issues by } \\
\text { postponement were } \\
\text { the highest (1.60) } \\
\text { before the practicum } \\
\text { and the lowest (1.42) } \\
\text { after the practicum. } \\
\text { They decreased as } \\
\text { participants } \\
\text { progressed in the } \\
\text { practicum. }\end{array}$ & & $\begin{array}{l}\text { Measurement was } \\
\text { performed based on } \\
14 \text { items of the Coping } \\
\text { Scale } \\
\text { - Scores for the } \\
\text { following coping } \\
\text { types in the Coping } \\
\text { Scale were slightly } \\
\text { higher in the study } \\
\text { compared to earlier } \\
\text { studies: the } \\
\text { problem-focused } \\
\text { type, the } \\
\text { emotion-centered } \\
\text { type, and the } \\
\text { avoidance/aversion } \\
\text { type. } \\
\text { - Scores in the Coping } \\
\text { Scale were low only } \\
\text { for "asking others to } \\
\text { help with resolving } \\
\text { issues." }\end{array}$ & $\begin{array}{l}\text { Measurement was } \\
\text { performed based on } 14 \\
\text { items of the Coping } \\
\text { Scale. } \\
\text { - There were no } \\
\text { changes in coping } \\
\text { between before and } \\
\text { after the practicum. } \\
\text { - Scores for "talking to } \\
\text { others about own } \\
\text { situations" were } \\
\text { higher after the } \\
\text { practicum than } \\
\text { before the } \\
\text { practicum. }\end{array}$ & $\begin{array}{l}\text { Measurement was } \\
\text { performed based on } 18 \\
\text { items of the BSCP. } \\
\text { - There was a negative } \\
\text { relationship between } \\
\text { "adjusting } \\
\text { autonomous nursing } \\
\text { practice with } \\
\text { teachers and } \\
\text { instructors" and } \\
\text { the BSCP item, } \\
\text { "active solution." }\end{array}$ \\
\hline Stress reaction & $\begin{array}{l}\text { Moods were measured } \\
\text { using } 30 \text { items of the } \\
\text { simple version of the } \\
\text { POMS. } \\
\text { - For coping with } \\
\text { positive relationships, } \\
\text { a significant positive } \\
\text { correlation was } \\
\text { observed only with } \\
\text { "V: vitality." }\end{array}$ & $\begin{array}{l}\text { Measurement was } \\
\text { performed based on the } \\
12 \text { items of the General } \\
\text { Health Questionnaire } \\
\text { (GHQ)-12 as well as a } \\
\text { psychological stress } \\
\text { questionnaire which was } \\
\text { examined and developed } \\
\text { by experienced } \\
\text { practicum instructors. }\end{array}$ & $\begin{array}{l}\text { Measurement was } \\
\text { performed based on } \\
\text { the } 12 \text { items of the } \\
\text { General Health } \\
\text { Questionnaire } \\
\text { (GHQ)-12 } \\
\text { - Compared to adults } \\
\text { in their 20s who } \\
\text { have a job, GHQ-12 } \\
\text { scores before the } \\
\text { practicum were } \\
\text { lower in participants. }\end{array}$ & $\begin{array}{l}\text { Measurement was } \\
\text { performed based } \\
\text { on the } 12 \text { items of } \\
\text { the General Health } \\
\text { Questionnaire } \\
\text { (GHQ)-12. } \\
\text { - For the level of } \\
\text { mental health, } \\
\text { scores for the factor, } \\
\text { "depression and } \\
\text { anxiety" and total } \\
\text { scores were } \\
\text { significantly higher } \\
\text { before the practicum. }\end{array}$ & \\
\hline
\end{tabular}




\section{Continued}

\begin{tabular}{|c|c|c|c|c|c|}
\hline Stress reaction & $\begin{array}{l}\text { - For coping with } \\
\text { negative } \\
\text { relationships, } \\
\text { significant positive } \\
\text { correlations were } \\
\text { observed with "TA: } \\
\text { tension and anxiety," } \\
\text { "D: depression," “AH: } \\
\text { anger and hostility," } \\
\text { "F: fatigue," and "C: } \\
\text { confusion." } \\
\text { - For coping with issues } \\
\text { by postponement, a } \\
\text { significant negative } \\
\text { correlation with "D: } \\
\text { depression" was } \\
\text { observed. }\end{array}$ & $\begin{array}{l}\text { - Mean scores for } \\
\text { physical symptoms } \\
\text { were significantly } \\
\text { higher for adult } \\
\text { nursing practicums, } \\
\text { whereas those for } \\
\text { psychological states } \\
\text { were higher for } \\
\text { psychiatric nursing } \\
\text { practicums. } \\
\text { A positive correlation } \\
\text { was observed between } \\
\text { the GHQ-12 and the } \\
\text { physical and } \\
\text { psychological stress } \\
\text { items, "physical } \\
\text { symptoms" and } \\
\text { "psychological states." } \\
\text { - There was a positive } \\
\text { correlation between } \\
\text { the GHQ-12 and } \\
\text { "hesitation for } \\
\text { practicums." }\end{array}$ & & & \\
\hline \multirow{2}{*}{ Discipline } & \multicolumn{5}{|c|}{ Other (no areas specified) } \\
\hline & 16 & 17 & 18 & 19 & 20 \\
\hline Paper No. & $\begin{array}{l}\text { The Relationship between } \\
\text { the Experience of Joy, } \\
\text { Self-Efficacy, } \\
\text { and Stress Reaction in } \\
\text { Nursing Students during } \\
\text { a Practicum }\end{array}$ & $\begin{array}{l}\text { Stressors for Spanish } \\
\text { Nursing Students in } \\
\text { Clinical Practice }\end{array}$ & $\begin{array}{l}\text { Stress and Coping } \\
\text { Strategies among } \\
\text { Saudi Nursing } \\
\text { Students during } \\
\text { Clinical Education }\end{array}$ & $\begin{array}{l}\text { Stressors and } \\
\text { Expectations of } \\
\text { Undergraduate } \\
\text { Nursing Students } \\
\text { during Clinical } \\
\text { Practice in Singapore }\end{array}$ & $\begin{array}{l}\text { Stress in Nursing } \\
\text { College Students } \\
\text { during a Clinical } \\
\text { Practicum }\end{array}$ \\
\hline Title & Kawashima et al. (2018) & Suarez-Garcia et al (2018) & Al-Gamal et al.(2018) & Suen, et al (2016) & Otani et al. (2015) \\
\hline Primary author & $\begin{array}{l}\text { To shed light on the } \\
\text { relationship between the } \\
\text { experience of joy, } \\
\text { self-efficacy, and stress } \\
\text { reaction in nursing } \\
\text { students during a } \\
\text { practicum and to identify } \\
\text { whether there are any } \\
\text { differences between } \\
\text { students in different years. }\end{array}$ & $\begin{array}{l}\text { To understand to what } \\
\text { degree nursing practicums } \\
\text { can be a stressor for } \\
\text { Spanish nursing students, } \\
\text { and identify their } \\
\text { stressors. }\end{array}$ & $\begin{array}{l}\text { To elucidate stress } \\
\text { levels in university } \\
\text { students in Saudi } \\
\text { Arabia and their } \\
\text { coping behaviors. }\end{array}$ & $\begin{array}{l}\text { To shed light on the } \\
\text { relationship between } \\
\text { stress from a nursing } \\
\text { practicum and } \\
\text { satisfaction with } \\
\text { learning in nursing } \\
\text { students. }\end{array}$ & $\begin{array}{l}\text { To elucidate stress in } \\
\text { nursing students } \\
\text { participating in a } \\
\text { clinical practicum. }\end{array}$ \\
\hline Aim & $\begin{array}{l}\text { - A total of } 86 \\
\text { fourth-year students } \\
\text { who had completed all } \\
\text { practicums and } 82 \\
\text { second-year students } \\
\text { who had competed a } \\
\text { basic nursing } \\
\text { practicum in the } \\
\text { nursing department of } \\
\text { University A. } \\
\text { The study was } \\
\text { conducted from July to } \\
\text { October } 2016 \text {. }\end{array}$ & $\begin{array}{l}\text { - A total of } 450 \\
\text { nursing students. } \\
\text { - The study was } \\
\text { conducted from January } \\
\text { to } \\
\text { April } 2016 \text {. }\end{array}$ & $\begin{array}{l}\text { A total of } 121 \\
\text { nursing students. }\end{array}$ & $\begin{array}{l}\text { - A total of } 285 \\
\text { nursing students } \\
\text { - The study was } \\
\text { conducted in } \\
\text { January } 2014 \text {. }\end{array}$ & $\begin{array}{l}\text { - A total of } 121 \\
\text { second-year students } \\
\text { in the Department of } \\
\text { Nursing I who had } \\
\text { completed Geriatric } \\
\text { Nursing Practicum I. } \\
\text { - A total of } 118 \\
\text { third-year students in } \\
\text { the Department of } \\
\text { Nursing I who had } \\
\text { competed all } \\
\text { practicums. } \\
\text { The study was } \\
\text { conducted from } \\
\text { November to } \\
\text { December } 2014 .\end{array}$ \\
\hline
\end{tabular}




\section{Continued}

Participant, study period

Stress factor

Sense of
coherence
The 41-item KEZKAK, which is a scale for measuring stressors for nursing students,

revealed:

- Feeling stressed particularly about the possibility of harming a patient

- Skill shortcomings

- Multiple assignments

- Contact with suffering patients

- Difficulties in communication

- Female students were experiencing a higher level of stress than their male counterparts
- Stress items common between second- and third-year students included the following: "creating records outside class hours requires a considerable amount of time," "being unable to take the time for sufficient sleep," and "being nervous during a briefing."

- Third-year students were experiencing a higher level of stress compared to second-year students.
- Students were engaging in problem-solving behaviors.

Individual-based behaviors led to the improved quality of care.
The assessment was based on 13 items of the Perceived Stress Scale, which is for measuring perceived stress.

- The highest level of perceived stress was associated with care.
- Students in higher years had higher levels of stress.

- There was a relationship between a sense of fulfillment in learning and stress in students.

fourth-year students.

The mean scores

were lower than

those of women,

which were $5.2 \pm 3.2$. 


\section{Continued}

\begin{tabular}{|c|c|}
\hline $\begin{array}{c}\text { Stress-coping } \\
\text { behavior }\end{array}$ & $\begin{array}{l}\text { A comparison } \\
\text { between second-year } \\
\text { and fourth-year } \\
\text { students found that } \\
\text { a number of } \\
\text { fourth-year students } \\
\text { were suffering from } \\
\text { poor mental health. } \\
\text { They were more } \\
\text { susceptible to stress } \\
\text { as they were } \\
\text { expected to have a } \\
\text { large amount of } \\
\text { knowledge and skills } \\
\text { for practicums in } \\
\text { each specialist area. }\end{array}$ \\
\hline Stress reaction & \\
\hline
\end{tabular}

In adult nursing practicums, approximately $80 \%$ of students found recording stressful (Kikuchi et al., 2018). In maternal health nursing practicum, participants were feeling stressed due to "frustration, anxiety, and nervousness along with a lack of practical nursing skills" (Nakajima \& Hayakawa, 2014). For nursing integration and practical practicums, participants found the following aspects stressful: "understanding roles within the hospital organization," and "the course of nursing in which students are assigned to multiple patients" (Yoshioka et al., 2019).

Moreover, a paper that was not categorized as any area or discipline reported that students were feeling stress from the possibility of harming a patient and multiple care-related assignments (Suarez et al., 2018).

\subsection{The Sense of Coherence of Nursing Students}

The sense of coherence of nursing students was predominantly measured by a SOC scale. A review of relevant papers found that SOC scores of students for Basic Nursing Practicum I were $49.6 \pm 9.3$ (Hongo et al., 2011) and 51.5 (Kaneko \& Momino, 2015a). The scores for Basic Nursing Practicum II were $55.5 \pm 8.1$ (Kaneko \& Momino, 2015b; Momino \& Kaneko, 2016), adult nursing practicums were $54.6 \pm 9.5$ (Yamanaka et al., 2018), and nursing integration and practical practicums were $51.3 \pm 4.6$ (Yoshioka et al., 2019).

An analysis of SOC scores for each nursing practicum found that, in Basic Nursing Practicum II, students with a high SOC score had high sense of comprehensibility, manageability, and meaningfulness than those with a low SOC score (Usui et al., 2014). For nursing integration and practical practicums, there was a negative relationship between the SOC item, "sense of meaningfulness" and the following stress factors: "practicing nursing as a member of a nursing team" and "adjusting autonomous nursing practice with teachers and instructors” (Yoshioka et al., 2019). 


\subsection{Stress-Coping Behaviors of Nursing Students}

Stress-coping behaviors of nursing students were predominantly measured by the Brief Scales for Coping Profile (BSCP). A review of relevant papers found that there was a significant negative correlation between SOC scores and avoidance and suppression such as coping with issues by postponement. For Basic Nursing Practicum II and home nursing practicums, participants with a low SOC score were likely to engage in avoidance and suppression (Usui et al., 2014; Inoue \& Totsuka, 2010). For psychiatric nursing practicums, there was also a significant negative correlation between the SOC item, "sense of meaningfulness" and coping with issues by postponement (Takahashi et al., 2011). For maternal health nursing practicums, a large number of participants were the "problem-focused" type, such as those who acquired knowledge through self-learning before the practicum (Nakajima \& Hyakawa 2014). For nursing integration and practical practicums, there was a negative relationship between "adjusting autonomous nursing practice with teachers and instructors" and the BSCP item "active solution.” It was reported that students were positively coping with stress after receiving instructions from teachers in resolving issues as well as building a relationship with others; in other words, students were proactively working toward self-improvement despite stress (Yoshioka et al., 2019). Meanwhile, a study on adult nursing practicums found that students with a high level of stress failed to cope with stress in a problem-focused manner. The study stated that educational support is needed for such students, including clarifying issues and illustrating specific behaviors (Kikuchi et al., 2018).

\subsection{Stress Reaction of Nursing Students}

The stress reactions of nursing students were predominantly measured by the Japanese version of the General Health Questionnaire (GHQ)-12. A review of relevant papers found that students had poor mental health with a low mental health score after the completion of a practicum in adult nursing (Kikuchi et al., 2018; Yamanaka et al., 2018). It was also reported that the condition of students who took part in a practicum in geriatric nursing was characterized by severe anxiety and depression, reduced motivation, and chronic fatigue (Tsutsumi et al., 2019). Meanwhile, another study reported that, for home nursing practicums, depression and anxiety of students were alleviated after the practicum (Inoue \& Totsuka, 2011).

\section{Discussion}

\subsection{The Trend in Studies on Stress in Nursing Practicums}

This study reviewed papers on stress in nursing practicums. It was found that 14 out of 20 papers studied only one institution. The findings from these studies reflect that: first, the practicum environment varies because the specific methods and details are at the discretion of each university (Ministry of Education, Culture, Sports, Science and Technology, 2020); and second, the reviewed studies 
aimed to examine how teachers understand the stress of the students they supervise in a practicum, and design specific support. However, most of them extracted and examined question items on stress factors for nursing practicums based on earlier studies. Only three papers examined the reliability and validity of stress factors and created a scale (Kaneko \& Momino, 2015a; Yoshioka et al., 2019). For future studies, it is important to develop a scale to objectively measure the stress factors of students in different types of nursing practicums and to improve stress research.

Meanwhile, a review by area found that, among the 20 papers, 15 focused on stress in the following areas: Specialty I, Specialty II, and the integrated area. However, no reports on pediatric nursing practicums were found. The Ministry of Education, Culture, Sports, Science and Technology (2020) states that a clinical practicum is an opportunity for students to build a relationship with those they care for, and develop problem-solving skills by providing support to people from diverse backgrounds. Students understand the development of pediatric patients and engage with them in a pediatric nursing practicum. They are expected to have a high level of interpersonal and problem-solving skills required to help pediatric patients use their capabilities to the maximum when providing support (Ojiro \& Naragino, 2010). However, students can no longer work with each pediatric patient for a long period as hospitals have been reducing the number of days of hospitalization for pediatric patients. It is assumed that students are experiencing various types of stress because they are required to make progress in the course of nursing within a limited time frame, and understand each pediatric patient while engaging in nursing practice. To elucidate stress factors in pediatric nursing practicums, and understand the SOC and stress-coping behaviors of students, it is necessary to accumulate relevant studies in the future.

\subsection{Stress Factors in Nursing Practicums}

Stress factors in nursing practicums that were common for all university years were: nursing course and recording tasks. Making progress in a nursing course is a required skill. Students need it to provide quality nursing care to different patients. However, students were found to be experiencing severe stress as they had to spend a considerable amount of time recording their practicum activities while working on learning modules and completing assignments for their patients (Masamura et al., 2003; Otani et al., 2015; Kikuchi et al., 2018). Through these findings, it was considered that teachers need to identify specifically which recording task poses stress on students, and refine the support system through different ways such as examining educational methods.

Furthermore, stress factors in nursing practicums were found to reflect the objectives of practicums. In Basic Nursing Practicum II, students experienced stress related to the nursing course because the practicum was the first opportunity for them to engage in it (Kaneko \& Momino, 2015b). Students who took part in a geriatric nursing practicum (Tsutsumi et al., 2019), a psychiatric nursing practicum (Kosaka \& Moon, 2010), and a maternal health nursing practicum 
(Nakajima \& Hayakawa, 2014) felt stress from providing nursing care according to the needs of each patient as these areas require extensive knowledge and skills to address the patient's development stage, physical condition, and other aspects. Moreover, students enrolled in a home nursing practicum (Inoue \& Totsuka, 2010) were feeling stress along with depression and anxiety before the practicum because they visited a patient's home to learn how to care for a patient living at home, and worked in a small team with a visiting nurse or individually during the practicum (Inoue \& Totsuka, 2010). Considering these findings, it is necessary for teachers to provide cross-sectional support to students in different disciplines by utilizing tools such as a portfolio, so that they can continue to learn. In doing so, teachers need to, for example, recognize the stress that students have experienced in each nursing practicum, predict the types of stress that students are likely to experience in the relevant practicum, and examine measures to address it.

\subsection{The Sense of Coherence of Nursing Students}

There was a tendency for SOC scores in nursing students to be higher than those in other university departments. Mean SOC scores in first- and second-year university students were $52.54 \pm 9.82$ (male students) and $50.07 \pm 9.62$ (female students) (Endo et al., 2013) and in health care colleges were $53.4 \pm 1.30$ (male students) and $48.6 \pm 0.97$ (female students) (Ochiai et al., 2011). As shown in the results section, there was a tendency for SOC scores in first- and second-year students in nursing departments to be higher. Students pursuing nursing tend to have a higher SOC score compared to those in other university departments because nursing students establish their identity at an early stage, and set clear career goals. Therefore, they are capable of overcoming difficulties that they may face while working toward achieving their goals.

Also, the total SOC score of novice nurses at the time of employment in FY 2010 was 54.5 points (960 nurses in 111 hospitals) (Nakajima, 2017). There was no significant difference between this score and the total SOC score for nursing integration and practical practicums (Yoshioka et al., 2019), which is reported in the results section. The objectives of nursing integration and practical practicums are: to help students integrate their knowledge and skills so that they can work in situations similar to real-world settings during the practicum; and to help students adapt to clinical settings without issues after graduation (Ministry of Health, Labour and Welfare, 2007). Hence, educational support for students to cope with stress following employment may play a significant role. Considering these findings, it is necessary for teachers to provide students with opportunities that allow them to think about their situation through nursing practice and collaboration with healthcare professionals, so that students can improve their capabilities related to the following subordinate SOC concepts: a sense of comprehensibility, manageability, and meaningfulness. It is also necessary for teachers to help students accumulate their experiences of successfully addressing stress by understanding their situation and utilizing their strengths and weak- 
nesses.

\subsection{Stress-Coping Behaviors of Nursing Students}

Students' stress-coping behaviors that were frequently observed were as follows: avoidance and suppression in Basic Nursing Practicum II (Usui et al., 2014); and active solution in nursing integration and practical practicums (Yoshioka et al., 2019). There was a tendency for students in Basic Nursing Practicum II to select avoidance and suppression, such as giving up on resolving issues, because they had difficulties in communicating with patients and instructors as well as recording their practicum work due to a lack of experience. Those in nursing integration and practical practicums were likely to select "active solution" rather than emotional reaction. It was considered that this is because the students understood what kind of stress-coping behaviors they are likely to use as they had successfully addressed various types of stress through the experience of the nursing practicum.

Meanwhile, it was pointed out that a certain number of students had a low score for "active solution" (Inoue \& Totsuka, 2010). Students who are likely to select avoidance and suppression may experience failure in addressing stress after they start their career as a nurse. Due to this, they may end up committing nursing malpractice or near misses. Therefore, teachers should help students learn from experience by objectively evaluating themselves through self-reflection, so that they understand how they are likely to cope with stress, and take actions accordingly.

\subsection{Stress Reaction of Nursing Students}

An analysis of the stress reaction of students in nursing practicums found that their General Health Questionnaire (GHQ)-12 scores were high during the practicum (Yamanaka et al., 2018; Kikuchi et al., 2018). Reduced thinking ability and concentration persisted even after the nursing practicum (Ogura \& Taniguchi, 2013). Certain students continued to have poor mental health even after they started their fourth year of study (Kawashima et al., 2018). Students interact with patients and their families as well as health professionals during a nursing practicum. They also experience events that they have never experienced before during a practicum, and are emotionally stimulated by such experience. Therefore, they may need help from others in coping with stress. Hence, teachers should encourage students to actively seek help. With this, teachers can proactively provide students with opportunities such as collaborative learning sessions and briefings, in which students can learn through interaction with others.

Also, students can suffer from poor physical and mental health if they accumulate experiences of failure in coping with stress. Therefore, the kinds of support that would be key in helping students manage their stress not only during but also after the practicum are: support from various other professionals such as student counselors, continuous engagement with students, and opportunities for reducing stress. 


\section{Conclusion}

This study proposed three suggestions for educational support by shedding light on the stress factors, SOC, stress-coping behaviors, and stress reaction of students regarding nursing practicums. First, cross-sectional support should be provided across different nursing practicums, so that students can recognize their stress, predict the types of stress that they are likely to experience during the practicum, and consider measures to address it. In doing so, a portfolio can be utilized. Second, opportunities for proactive thinking should be provided to students so that they understand their current situation, and have experiences of successfully coping with stress by utilizing their strengths and weaknesses. Third, students should be encouraged to practice self-reflection so that they can objectively evaluate how they are likely to address their stress, and learn to cope with stress from experience.

\section{Conflicts of Interest}

The authors declare no conflicts of interest regarding the publication of this paper.

\section{References}

Antonovsky, A. (1987). Unraveling the Mystery of Health: How People Manage Stress and Stay Well. Yushindo.

Endo, S., Mituishi H., Kazu, H., \& Oishi, K. (2013). An Examination of the Reliability and the Validity of a One-Factor Model in the Thirteen-Item Seven-Point Sense of Coherence Scale (SOC-13). Bulletin of the College of Community and Human Services Rikkyo University, 15, 25-38.

Gamal, E., Alhosain, A., \& Alsunaye, K. (2018). Stress and Coping Strategies among Saudi Nursing Students during Clinical Education. Perspectives in Psychiatric Care, 54, 198-205. https://doi.org/10.1111/ppc.12223

Hasegawa, N., Ozawa, K., \& Takeshita, M. (2010). Confidence and Hesitation to Career Choice That Nursing Student Holds After the First Fundamental Nursing Practice. Bulletin of Aichi Kiwami College of Nursing, 6, 59-63.

Hongo, A., Takahashi, Y., \& Furuichi, K. (2011). The Relationships among Self Consciousness, Other-Consciousness and Sense of Coherence. Bulletin of Faculty of Nursing, Jobu University, 6, 1-8.

Inoue, M., \& Totsuka, T. (2010). Stressors for Students before a Community Nursing Practicum, and Their Coping Behaviors. Bulletin of Yokohama Soei Junior College, 6, 55-63.

Inoue, M., \& Totsuka, T. (2011). The Relationship between the Level of Mental Health and Coping in Community Nursing Practicums: A Comparative Examination before and after the Practicum. Bulletin of Yokohama Soei Junior College, 7, 79-56.

Kageyama, T., \& Kobayashi, T. (2017). Facing Stress While Maintaining Mental Health. Kongo Shuppan.

Kaneko, S., \& Momino, K. (2015a). Stress Factors and Coping Behaviors of Nursing Students during Fundamental Clinical Practice. Bulletin of Nagoya City University School of Nursing, 14, 51-57.

Kaneko, S., \& Momino, K. (2015b). Stress Factors and Coping Behaviors in Nursing Stu- 
dents during Fundamental Clinical Training in Japan. International Journal of Nursing \& Clinical Practice, 2, Article No. 138.

https://doi.org/10.15344/2394-4978/2015/138

Kawashima, Y., Tuchiya, A., Nishii, H. et al. (2018). The Relationship between the Experience of Joy, Self-Efficacy, and Stress Reaction in Nursing Students during a Practicum. Wakayama Medical University Journal of Health and Nursing Science, 9, 24-32.

Kikuchi, Y., Yoshioka, S., Kubota, M. et al. (2018). Changes in Mental Health Status and Stress/Coping of Students in Nursing Practice for the Perioperative/Acute Periods. Journal of the International University of Health and Welfare, 23, 137-144.

Kosaka, Y., \& Monn, J. (2010). Psychological Stress of Nursing Students in Psychiatric Mental Health Nursing Practice. Taisei Gakuin University Bulletin, 12, 171-176.

Masamura, K., Iwamoto, M., \& Ichihara, K. et al. (2003). Relationships between Student Nurses Stress and Daily Life When Engaged in Clinical Practice. Yamaguchi Medical Journal, 52, 13-21.

Ministry of Education, Culture, Sports, Science and Technology (2020). Nursing Practicum Guidelines. https://www.mext.go.jp/content/20200330-mxt_igaku-000006272_1.pdf

Ministry of Health, Labour and Welfare (2007). A Report on the Discussion Meeting on the Improvement of Basic Nursing Education. https://www.mhlw.go.jp/shingi/2007/04/dl/s0420-13.pdf

Momino, K., \& Kaneko, S. (2016). Changes in Sense of Coherence (SOC) among Nursing Students Undergoing Fundamental Nursing Clinical Practice, and Related Stress Factors. Bulletin of Nagoya City University School of Nursing, 15, 15-21.

Munakata, H. (2000). Looking at Health and Disease through the Prism of the Latest Behavioral Science. Medical Friend.

Nakajima, F. (1990). Recognizing the Stress of Students in Clinical Practicums. In The Proceeds of the 10th Academic Conference of the Japanese Nursing Association on Nursing Education (pp. 206-208). Japanese Nursing Association.

Nakajima, F. (2017). Support for Novice Nurses in Adapting to the Workplace: Overcoming Difficulties. Doctoral Dissertation, Kyoto University Research Information Repository. https://repository.kulib.kyoto-u.ac.jp/dspace/handle/2433/218021

Nakajima, K., \& Hyakawa, Y. (2014). Assignment of Maternal Nursing Practicum against Student's Stress and Coping. Bulletin of Gumma Paz College, 17, 53-63.

Ochiai, R., Daitou, S., \& Aoki, K. (2011). The Relations of the Sense of Coherence and Lifestyles to Self-Related Health for College Students. Journal of Health Sciences of Mind and Body, 7, 35-40.

Ogura, Y., \& Taniguchi, M. (2013). Stress of the Student in Maternity Science of-Nursing Training Male and Female Comparison. Bulletin of Faculty of Nursing of Chukyo Gakuin University, 3, 43-50.

Ojiro, H., \& Narakino, H (2010). Factors that Cause Nursing Students to Hesitate in Interacting with Children during Pediatric Nursing Practicums. Journal of Japanese Society of Nursing Research, 33, 69-76.

Otani, M., Deishi, K., Fujimura, R. et al. (2015). Stress in Nursing College Students during a Clinical Practicum. The Journal of Aichi Prefectural School of General Nursing, 10, 20-30.

Suarez, G., Maestro, G., Zuazua, R., Sánchez-Zaballos, M., \& Mosteiro-Diaz, M.P. (2018). Stressors for Spanish Nursing Students in Clinical Practice. Nurse Education Today, 64, 16-20. https://doi.org/10.1016/j.nedt.2018.02.001 
Suen, W., Lim, S., Wang, W., \& Kowitlawakul, Y. (2016). Stressors and Expectations of Undergraduate Nursing Students during Clinical Practice in Singapore. International Journal, 22, 574-583. https://doi.org/10.1111/ijn.12473

Takahashi, Y., Hongo, A., Furuichi, K. et al. (2011). Interpersonal Stress Coping of Nursing Students in Psychiatric Mental Health Nursing Practice. Bulletin of Faculty of Nursing, Jobu University, 6, 9-19.

Tsutsumi, M., Kawamura, A., \& Kiyonaga, A. (2019). Relationship between Stress Responses of Nursing Students and Their Active/Rest Patterns and Attainment Level in Geriatric Nursing Practice. Japanese Journal of Medical and Nursing Education, 28, 53-61.

Usui, M., Kaneko, S., \& Momino, K. (2014). Relationship between Stress Coping Skills and Stress Factors during Clinical Practice of Nursing Students. Bulletin of Nagoya City University School of Nursing, 13, 27-35.

Yamanaka, M., Hiraga, M., Fujiwara, N. et al. (2018). The Survey on Relationship and Change of the Sense of Coherence and Mental Health Status, Physical Symptoms, Life Situations and Social Situations in Nursing Students before and during Clinical Practice of Adult Nursing. Journal of Japan Academy of Nursing Education, 28, 1-11.

Yoshioka, E., Imoto, E., \& Kaneko, S. (2019). Stress Factors and Stress Coping Competence and Behavior among Nursing Students Providing Nursing Comprehensive Practice. Journal of the Japanese Society for the Study of Nursing and Social Work, 25, 227-240. 